\title{
A NOTE ON DATING, MONEY,
}

\section{AND MEASUREMENT}

\section{DATING}

Siena followed the Florentine style, beginning each new year with the Annunciation on 25 March, rather than on the preceding I January. Dates below are given in the common style unless specifically indicated as Sienese style.

\section{MONEY}

The Sienese lira was a money of account and not a coin. It was reckoned at 20 soldi or 240 denari; i.e., $\oint^{\text {s.d. }}$. For the changing relationship between the Sienese coinage (and hence also of the money of account) and the gold florin, see below, Ch. VI.

\section{MEASUREMENT}

Land measurement: The principal Sienese unit of surface measurement, the staio or starius, probably was slightly less than a third of an acre; but the "modern" equivalents for measurements in use in the eighteenth century may inadequately represent measurements in use during the thirteenth and fourteenth centuries.

Dry measure: A principal Sienese unit of dry measure, the staio or starius, was about a bushel. Twenty-four staia equal one moggio or modius. The size of the staio varied from one city to another. 
